\title{
Effects of Artemisia herba-alba or olive leaf (Olea europaea) powder supplementation on growth performance, carcass yield, and blood biochemical parameters in broilers
}

\author{
Asma Ait-Kaki ${ }^{1}$, Mamadou Tandiang Diaw², Fikremariam Geda ${ }^{3}$ and Nassim Moula ${ }^{3}$
}

1. Department of Biology, Faculty of Sciences, M'Hamed Bougara University of Boumerdes, 3500 Boumerdes, Algeria; 2. Department of Animal Production, ENSA, Thies University, BP A296 Thies, Senegal; 3. Department of Animal Production, Fundamental and Applied Research for Animal and Health, Faculty of Veterinary Medicine, Liege University, B-4000 Liege, Belgium.

Corresponding author: Nassim Moula, e-mail: Nassim.Moula@uliege.be

Co-authors: AA: askaki.biotechno@gmail.com, MTD: mtdiaw@univ-thies.sn,FG: fikremgeda@gmail.com Received: 13-07-2018, Accepted: 11-10-2018, Published online: 26-11-2018

doi: 10.14202/vetworld.2018.1624-1629 How to cite this article: Ait-Kaki A, Diaw MT, Geda F, Moula N (2018) Effects of Artemisia herba-alba or olive leaf (Olea europaea) powder supplementation on growth performance, carcass yield, and blood biochemical parameters in broilers, Veterinary World, 11(11): 1624-1629.

\begin{abstract}
Aim: This study was aimed to evaluate the effects of Artemisia herba-alba (white wormwood) or olive leaf (Olea europaea) powder supplementation on growth performance, carcass yield, and serum biochemical parameters in broilers.

Materials and Methods: The study was conducted from April to May 2017 in Chemini region, Northern Algeria. A total of 60 1-day-old Ross 308 male chicks were divided into three groups consisted of 10 chicks, in each of two replications. The chicks in Group 1 were fed with a standard commercial diet (SCD); Group 2 received the same SCD with 2\% supplementation of $A$. herba-alba powder; and Group 3 received the same SCD with $2 \%$ supplementation of $O$. europaea powder. Growth performance was measured with body weights every 2 weeks, daily feed intake, feed conversion ratio (FCR), and carcass yield at the end of 42 days of rearing. Blood samples were collected to analyze serum glucose, cholesterol, triglycerides, urea, and total protein levels.
\end{abstract}

Results: Results showed that, at 42 days of rearing, supplementation of $O$. europaea and A. herba-alba significantly increased $(\mathrm{p}<0.001)$ mean body weight $(2230.10 \pm 26.38 \mathrm{~g}$ and $2117.42 \pm 26.38 \mathrm{~g}$, respectively, vs. $2336.66 \pm 27.88 \mathrm{~g}$ in chicks of Group 1), but there was no significant difference $(\mathrm{p} \geq 0.05)$ among the three diets for FCR or percentage carcass yield. Among the serum biochemical parameters, glucose was significantly affected $(p<0.01)$ by supplementation of olive leaf powder (1.90 g/L: Group 3), compared to the SCD (2.24 g/L: Group 1) or Artemisia powder (2.05 g/L: Group 2). Moreover, the supplementation of olive leaf powder in Group 3 broilers significantly affected $(\mathrm{p}<0.05)$ the serum cholesterol level $(0.95 \mathrm{~g} / \mathrm{L})$, compared to the control diet $(1.13 \mathrm{~g} / \mathrm{L})$. There was no significant difference $(\mathrm{p} \geq 0.05)$ for the other selected serum biochemical concentrations, namely triglycerides, urea, and total protein.

Conclusion: The supplementation of Artemisia or olive leaf powder into the diet for broilers improved body weight by about $5 \%$ or $10 \%$, respectively, at slaughter with moderate changes in blood biochemical parameters.

Keywords: Artemisia herba-alba, broiler, growth, Olea europaea, serum parameters.

\section{Introduction}

Intensive poultry production in Algeria depends on exotic chicken strains and on imported feed ingredients such as soybean, corn, and mineral-vitamin complexes, which weaken the national poultry sector. In fact, the international price fluctuations of these feed ingredients destabilize the national markets and favor informal activities that are less controlled by public authorities. This increases the use of uncontrolled veterinary drugs (antibiotics, anticoccidials, and vaccines) for preventive purposes or as growth factors.

Copyright: Ait-Kaki, et al. Open Access. This article is distributed under the terms of the Creative Commons Attribution 4.0 International License (http://creativecommons.org/licenses/ by/4.0/), which permits unrestricted use, distribution, and reproduction in any medium, provided you give appropriate credit to the original author(s) and the source, provide a link to the Creative Commons license, and indicate if changes were made. The Creative Commons Public Domain Dedication waiver (http:// creativecommons.org/publicdomain/zero/1.0/) applies to the data made available in this article, unless otherwise stated.
In Algeria, poultry production is mainly concentrated in northern cities where several medicinal plants, for instance, Urtica dioica (Azeghdhouf in Kabyle), Artemisia herba (Ifsi in Kabyle), and Olea europaea (Azemmour in Kabyle) are widely identified and used in traditional medicine. On the basis of their medicinal and nutritional properties, it is necessary to evaluate their potential as ingredients in animal nutrition through their effects on performance and biochemical parameters.

$A$. herba, also known as white wormwood, was described by Belhattab et al. [1], as dwarf shrub, and characterized by a thymol scent. Mahmoodly [2] reported its significant use in African folk medicine. Indeed, Artemisia is known for its anti-inflammatory effects [3], hypocholesterolemia, and hypotriglyceridemia [4-7]. In folk medicine, in Kabyle region of Algeria, this grass is used to treat several symptoms such as digestive problems (diarrhea and stomach upset) and respiratory problems (bronchitis and 
cough). Furthermore, antihelminthic and antileishmanial effects of Artemisia were reported in several studies [4,8-10].

The olive tree (O. europaea) is a millenary tree grown on the northern and southern coastal zones of the Mediterranean Sea. Olives and olive oil are the main products of the olive tree; the leaves are used in cosmetics, animal feed, and traditional medicine. Several studies have reported the hypotensive [11-13], hypoglycemic $[14,15]$, and anti-infectious $[16,17]$ effects of olive leaves.

This study aimed to evaluate the effects of supplementation of $A$. herba-alba or olive leaf (O. europaea) powder on growth performance, carcass yield, and serum biochemical parameters in broilers in a private farm located in Chemini, Bejaia, Algeria.

\section{Materials and Methods}

\section{Ethics approval}

Due to the lack of animal ethics commission in Algeria, the authors followed the regulations applied in Liege University, Belgium.

\section{Preparation and chemical composition of Artemisia or olive leaf powder}

For this study, the olive leaves were harvested during the olive harvesting period (December 2016-February 2017) in the region of Chemini (Bejaia wilaya), about $260 \mathrm{~km}$ east of Algiers, the capital of Algeria. After traditionally drying the leaves, the leaves were transformed to powder using a cereal mill. Another ingredient used as a supplementation, A. herba-alba, was obtained from Bouhamza and Akbou regions (wilaya of Bejaia). The same drying techniques were used for the two plants; the final products were analyzed at the Laboratory of Forage Analysis (Department of Agricultural and Environmental Analyses, Province of Liege, Belgium). The parameters measured were dry matter (DM), crude protein $(\mathrm{CP})$, crude fiber $(\mathrm{CF})$, crude ash (CA), and selected macro and micro minerals (Table-1).

\section{Animals and housing}

The experiment was carried out for a rearing period of 42 days in a private farm located in Chemini, Bejaia, Algeria. A total of 60, 1-day-old Ross 308 male chicks (commercial strain) were divided into three groups consisted of 10 chicks, in each of two replications. The chicks in Group 1 were fed with a standard commercial diet (SCD); Group 2 received the same SCD with $2 \%$ supplementation of $A$. herba-alba powder; and Group 3 received the same SCD with $2 \%$ supplementation of $O$. europaea powder. The chicks were housed under identical conditions and provided lighting $16 \mathrm{~h} /$ day using fluorescent lights controlled by timers until the end of the experiment.

\section{Growth performance and carcass yield}

A progressive feed transition was made between each rearing phase (starter, grower, and finisher). The feed was given ad libitum to the three groups, and the
Table-1: Dietary ingredients of SCD for starter, grower, and finisher period and nutrient composition of Artemisia or olive leaf powder.

\begin{tabular}{|c|c|c|c|}
\hline Ingredients (\%) & Starter & Grower & Finisher \\
\hline Corn & 62 & 64 & 70 \\
\hline Soybean meal & 30 & 28 & 22 \\
\hline Bran & 5 & 5 & 5 \\
\hline Monocalcium phosphate & 2 & 2 & 2 \\
\hline Premix & 1 & 1 & 1 \\
\hline \multicolumn{4}{|l|}{ Nutrient level } \\
\hline $\begin{array}{l}\text { Metabolizable } \\
\text { energy }(\mathrm{kcal} / \mathrm{kg})\end{array}$ & 2912 & 2933 & 2995 \\
\hline $\mathrm{CP}(\%)$ & 20.45 & 19.75 & 17.66 \\
\hline \multicolumn{4}{|l|}{$\begin{array}{l}\text { Calculated nutrient } \\
\text { composition }\end{array}$} \\
\hline $\begin{array}{l}\text { Analytical composition } \\
(\mathrm{g} / \mathrm{kg})\end{array}$ & $\begin{array}{l}\text { Artemisia } \\
\text { powder }\end{array}$ & $\begin{array}{c}\text { Olive leaf } \\
\text { powder }\end{array}$ & \\
\hline DM & 895 & 816 & \\
\hline $\mathrm{CP}$ & 103 & 74 & \\
\hline $\mathrm{CF}$ & 296 & 187 & \\
\hline $\mathrm{CA}$ & 126 & 77 & \\
\hline \multicolumn{4}{|l|}{ Macro minerals $(\mathrm{g} / \mathrm{kg})$} \\
\hline Calcium & 10.6 & 18.1 & \\
\hline Phosphorus & 3.3 & 1.4 & \\
\hline Potassium & 35.5 & 7.6 & \\
\hline Sodium & 0.4 & 0.2 & \\
\hline Magnesium & 2.5 & 2.9 & \\
\hline \multicolumn{4}{|l|}{ Micro minerals $(\mathrm{mg} / \mathrm{kg})$} \\
\hline Copper & 15.1 & NM & \\
\hline Iron & 299.7 & NM & \\
\hline Manganese & 87.8 & NM & \\
\hline Zinc & 31.0 & NM & \\
\hline
\end{tabular}

$\mathrm{SCD}=$ Standard commercial diet; $\mathrm{DM}=$ Dry matter; $\mathrm{CP}=$ Crude protein; $\mathrm{CF}=$ Crude fiber; $\mathrm{CA}=$ Crude ash $\mathrm{NM}=$ Not measured

chicks were monitored daily to weigh the amounts of feed distributed and refused in the feeders. The mortality rate was determined as the percentage of the number of chicks died relative to their number at the beginning of the rearing period. Animals were individually weighed every 2 weeks, during the 42 days of rearing. The feed conversion ratio (FCR) of each group was calculated at the end of the experiment as a ratio of the amount of feed ingested during the rearing period to total weight gain. Toward the end of the experiment, the chicks were starved for about $12 \mathrm{~h}$ and slaughtered. Then, the animals were manually scalded and plucked. $1 \mathrm{~h}$ after the slaughter, carcass weight was calculated by removing feathers, blood, head, tarsus, and organs; carcass yield was measured as the ratio of the carcass weight to live weight multiplied by 100 and reported as percentage carcass yield.

\section{Serum biochemical analysis}

Pre-slaughter blood samples were taken from the wing vein on five subjects of each batch (10 samples/group). Blood serum samples were collected and stored at $-20^{\circ} \mathrm{C}$ until analyzed for serum glucose, cholesterol, triglycerides, urea, and total protein, which were determined using a spectrophotometer (LKBNovastec) and commercially available kits (SPINREACT, SA, Spain). The serum concentrations of glucose, cholesterol, triglycerides, and total protein 
were determined using the methods such as glucose oxidase-peroxidase, cholesterol oxidase-peroxidase (PAP), glycerol phosphate-PAP enzyme, and biuret (colorimetric test), respectively.

\section{Statistical analysis}

The statistical analysis was performed using the SAS software (GLM procedure, SAS Institute, Inc., Cary, NC., USA) [18]. Data were verified for the hypothesis of normality, and the live weights were analyzed with a GLM including the fixed effects of diet (Groups 1, 2, and 3), age (d0, d14, d28, and d42), replication ( 1 and 2 ), and the age $\times$ diet interaction. One-way analysis of variance was performed to compare the FCR of the three diets and to identify the diet effect on the results of serum concentrations. Results were expressed as means and standard error of means unless otherwise stated. $p<0.05$ was considered to be statistically significant.

\section{Results}

\section{Artemisia or olive leaf powder analysis}

The analytical composition of Artemisia or olive leaf powder is reported in Table-1. The results of the analysis indicated that $\mathrm{CP}, \mathrm{CF}$, and CA contents were higher in Artemisia compared with olive leaves. However, olive leaves were more concentrated in calcium (18.1 vs. $10.6 \mathrm{~g} / \mathrm{kg}$ ) than Artemisia whose composition in potassium was higher $(35.5 \mathrm{vs} .7 .6 \mathrm{~g} / \mathrm{kg})$.

\section{Growth performance and carcass yield}

The growth performance and percentage carcass yield of the three groups of broilers are reported in Table-2. The results indicated that there was no significant effect of replication ( $\mathrm{p} \geq 0.05)$ on the evolution of the weights with the age of the chicks. At the end of 42 days of the rearing period, supplementation of O. europaea significantly increased mean body weight
( $<<0.001 ; 2117.42 \mathrm{~g}, 2230.10 \mathrm{~g}$, and $2336.66 \mathrm{~g})$, but there was no significant difference $(\mathrm{p} \geq 0.05)$ among the three diets for FCR $(1.79,1.87$, and 1.81) or percentage carcass yield $(70.52,71.84$, and 70.21$)$, respectively, in Groups 1, 2, and 3. Of course, the mean body weights at day 0 showed that there was no significant difference $(\mathrm{p} \geq 0.05)$ among the groups at the beginning of the experiment (Group 1: $39.86 \mathrm{~g}$, Group 2: $38.82 \mathrm{~g}$, and Group 3: $39.96 \mathrm{~g}$ ). The average daily gain of Group 3 was the highest followed by Groups 2 and 1, respectively; daily feed intake was not significantly different between the diets $(\mathrm{p} \geq 0.05)$. Furthermore, at the end of the experiment, mortality rates were 5,10, and $15 \%$ for the Groups 1,2, and 3, respectively, with 1, 2, and 3 chicks died in that order.

\section{Serum biochemical analysis}

The mean serum concentrations of glucose, cholesterol, triglycerides, urea, and total protein are reported in Table- 3 . The results showed that, at the end of 42 days of the rearing period, glucose was significantly affected $(p<0.01)$ by supplementation of olive leaf powder (Group 3: $1.90 \mathrm{~g} / \mathrm{L}$ ), compared to the SCD (Group 1: $2.24 \mathrm{~g} / \mathrm{L}$ ) or Artemisia powder (Group 2: $2.05 \mathrm{~g} / \mathrm{L}$ ). Moreover, the supplementation of olive leaf powder in Group 3 broilers significantly affected the serum cholesterol level $(\mathrm{p}<0.05$; Group 3: $0.95 \mathrm{~g} / \mathrm{L}$ and Group 2: $1.03 \mathrm{~g} / \mathrm{L}$ ), compared to the control (Group 1: $1.13 \mathrm{~g} / \mathrm{L}$ ) diet. There was no significant difference $(\mathrm{p} \geq 0.05)$ among the groups regarding the other selected serum biochemical concentrations, namely triglycerides, urea, and total protein.

\section{Discussion}

\section{Artemisia or olive leaf powder}

A. herba-alba is a North African species belonging to Asteraceae family. It is very popular on the

Table-2: Effect of Artemisia or olive leaf powder on growth performance and carcass yield of broilers (mean, pooled SEM).

\begin{tabular}{|c|c|c|c|c|c|c|c|c|}
\hline \multirow[t]{2}{*}{ Age } & \multicolumn{3}{|c|}{ Diets } & \multirow[t]{2}{*}{ Pooled SEM } & \multicolumn{4}{|c|}{ p-value } \\
\hline & Group 1 & Group 2 & Group 3 & & Replication & Age & Diet & Age $\times$ diet \\
\hline \multicolumn{9}{|l|}{ Live weight $(\mathrm{g})$} \\
\hline Day 0 & 39.86 & 38.82 & 39.96 & 25.70 & NS & $* *$ & $* *$ & * \\
\hline Day 14 & 273.71 & 339.67 & 347.15 & 26.62 & & & & \\
\hline Day 28 & $950.95^{\mathrm{a}}$ & $1019.13^{b}$ & $1095.47^{b}$ & 26.62 & & & & \\
\hline Day 42 & $2117.42^{\mathrm{a}}$ & $2230.10^{\mathrm{b}}$ & $2336.66^{c}$ & 27.12 & & & & \\
\hline \multicolumn{9}{|l|}{ ADG (g/day) } \\
\hline Days $0-14$ & 16.71 & 21.49 & 21.94 & & - & - & - & - \\
\hline Days $14-28$ & 48.37 & 48.53 & 53.45 & & - & - & - & - \\
\hline Days 28-42 & 83.32 & 86.48 & 88.68 & & - & - & - & - \\
\hline Days $0-42$ & 49.47 & 52.17 & 54.68 & & - & - & - & - \\
\hline Feed intake (days $0-42, \mathrm{~g}$ ) & 3790.18 & 4170.23 & 4229.35 & & - & - & - & - \\
\hline FCR (days 0-42) & 1.79 & 1.87 & 1.81 & & - & - & - & - \\
\hline Mortality: Number (\%) & $1(5)$ & $2(10)$ & $3(15)$ & & - & - & - & - \\
\hline \multicolumn{9}{|l|}{ Carcass } \\
\hline Yield (\%) & 70.52 & 71.84 & 70.21 & 0.57 & NS & - & NS & NS \\
\hline
\end{tabular}

Group 1=Control SCD; Group 2: SCD+2\% Artemisia herba-alba; Group 3: SCD+2\% Olea europaea leaf. Within a row, mean values with different letters were significantly different $(p<0.05) ; * *=p<0.001 ; *=p<0.01 ; N S=p \geq 0.05$; $\mathrm{SEM}=$ Standard error of means; $\mathrm{FI}=$ Feed intake; $\mathrm{FCR}=$ Feed conversion ratio; $\mathrm{ADG}=$ Average daily gain; $\mathrm{SCD}=\mathrm{Standard}$ commercial diet 
Table-3: Effect of Artemisia or olive leaf powder on selected serum biochemical parameters of broilers (mean, pooled SEM).

\begin{tabular}{|c|c|c|c|c|c|c|}
\hline \multirow[t]{2}{*}{ Parameters (g/L) } & \multicolumn{3}{|c|}{ Diet group } & \multirow[t]{2}{*}{ Pooled SEM } & \multicolumn{2}{|c|}{ p-value } \\
\hline & Group 1 & Group 2 & Group 3 & & Replication & Diet group \\
\hline Glucose & $2.24^{\mathrm{a}}$ & $2.05^{\mathrm{a}}$ & $1.90^{\mathrm{b}}$ & 0.06 & $*$ & $* *$ \\
\hline Cholesterol & $1.13^{\mathrm{a}}$ & $1.03^{\mathrm{ab}}$ & $0.95^{b}$ & 0.05 & NS & NS \\
\hline Triglycerides & 0.73 & 0.69 & 0.68 & 0.04 & NS & NS \\
\hline Urea & 0.032 & 0.033 & 0.036 & 0.002 & NS & NS \\
\hline Total protein & 26.66 & 27.11 & 26.02 & 0.77 & NS & NS \\
\hline
\end{tabular}

Group 1=Control SCD; Group 2=SCD+2\% Artemisia herba-alba; Group 3=SCD+2\% Olea europaea leaf; Within a row, mean values with different letters were significantly different $(p<0.05) ; * *=p<0.01 ; *=p<0.05 ; N S=p \geq 0.05$; $\mathrm{SEM}=$ Standard error of means; $\mathrm{SCD}=$ Standard commercial diet

steppes and the highlands of Algeria. In the steppes, for main rangelands of nomadic sheep production in Algeria, Artemisia represents an important fodder resource. According to some testimonials, Artemisia is also used for therapeutic purposes for humans and animals in Kabyle region of Algeria. It is used to ease digestion and soothe abdominal and liver pains; in addition, it is used as a dewormed and against diabetes. Steppes of white wormwood (A. herba-alba) have been continued to be among the best steppe rangelands in the high plains of Algeria [19].

Like other olive-growing regions, in Kabyle (Algeria), farmers traditionally distribute olive branches to animals either at trough or in field. It is difficult to estimate the percentage reserved for this use because it varies considerably from country to country. Anyways, the ad libitum distribution to ruminants does not pose any particular problem, except for the limited nutritional value of this feed. The fresh leaves and twigs were distributed in Greece to sheep and goats at $6 \%$ of animal live weight as the only feed and up to $10 \%$, in the case of rabbits [20]. However, Zoiopoulos [21] suggested that the optimum level would be at $2.5 \%$ of live weight for ruminants.

Muñoz et al. [22] studied ad libitum diets of dried olive leaves, supplemented with a barley and a dried fishmeal protein ( $230 \mathrm{~g} / \mathrm{lamb} /$ day $)$, distributed to lambs weighing $36 \mathrm{~kg}$, and reported a weight gain of $77 \mathrm{~g}$ /day, compared to lambs received $40 \mathrm{~g}$ of the same feed supplemented with urea in Spain. However, the control group consumed alfalfa hay and $200 \mathrm{~g}$ of barley had an increase of $154 \mathrm{~g}$ /day over 90 days. Moreover, Alibes and Berge [23] recommended the use of dried olive leaves like that of poor forages with protein supplement, some easily fermentable energy input, and mixture of minerals.

From practical point of view, little effort has been made in this region. For instance, Nigh [24] reported that, in Crete at the Kolymbari Center, the olive leaves collected from the oil mill were distributed fresh $(<2$ days old) at a rate of $15 \mathrm{~kg} /$ day to Holstein cows. Zoiopoulos [21] noted that currently, the distribution level of these fresh leaves has reached $30 \mathrm{~kg} /$ day for two meals. Similar amounts are distributed as silage after the harvest period. Although precise controls have not been scientifically performed, the author indicated a positive effect on milk production. Fresh leaves are also sometimes distributed to sows.

\section{Chemical composition of Artemisia or olive leaf powder}

Chemical composition of Artemisia or olive leaf powder is presented in Table-1, with higher levels of $\mathrm{CP}$ and $\mathrm{CF}$ in Artemisia. The $\mathrm{CP}$ and CA contents of olive leaves are $11.8 \%$ and $18.7 \%$ of DM, respectively. The CP level reported in this study is closer to that reported by Cayan and Erener [25] and similar to the result of Fall-Touré et al. [26] but with leaves of Faidherbia albida. However, the CA content is 8 -folds higher than the value reported by Cayan and Erener [25]. The chemical compositions of olive leaves and twigs depend on many factors such as variety of olive trees, agroclimatic conditions, time of sample collection, and different treatments. According to Alibes and Berge [23], the DM of fresh leaves is around $50 \%$, while that of dry leaves is around $90 \%$. The CP level in dry or insulated leaves is low, ranging from $7 \%$ to $8 \%$, but slightly higher for fresh leaves. The fat content in olive leaves is about $6 \%$, which is higher than that in conventional forages. The CF content is moderately variable. The content of parietal constituents substantially increases with the proportion of wood, especially the lignocellulose content; the level of lignin appears stable: $18-19 \%$.

$A$. herba-alba has a much lower percentage of fiber which allows prejudging its appearance (17-33\%). The DM contains between 6\% and 11\% CP, which consists $72 \%$ of amino acids. Beta-carotene levels vary between 1.3 and $7 \mathrm{mg} / \mathrm{kg}$ depending on the season [27]. The values recorded in the present study for CF $(29.6 \%)$ and total nitrogen content $(16.5 \%)$ are closer to those reported by Fenardji et al. [27]. The energy value of Artemisia is very low in the winter (0.2-0.4 UF/ $\mathrm{kg} \mathrm{DM})$, increases rapidly in the spring (0.92 UF/ $\mathrm{kg} \mathrm{DM})$, and decreases in the summer (0.6 UF $/ \mathrm{kg} \mathrm{DM})$. In the autumn, the rain in September causes a new period of growth, and the energy value rises again $(0.8 \mathrm{UF} / \mathrm{kg} \mathrm{DM})$ [28]. These nutritional content values make the plant very important in sheep production in Algeria.

The proportions of $\mathrm{CP}$ and $\mathrm{CA}$ in the $\mathrm{DM}$ of A. herba-alba are $10.3 \%$ and $12.6 \%$, respectively. The Artemisia CP level reported in this study is higher than 
those found in stems and roots of Artemisia annua L. by Jae et al. [29] but remains well below than values reported by the same authors in leaves and in the inflorescence of the same species. These variations in Artemisia nutrient content according to the authors and diverse varieties used could be explained by several parameters such as origins and methods of cultivation, period of harvest, technology used during the harvest period, and methods of drying leaves [30-32].

\section{Growth performance and carcass yield}

After 42 days of the rearing period, the mean weights of the three feeding groups, namely Group 1 (control, SCD), Group $2(\mathrm{SCD}+2 \%$ A. herba-alba), and Group 3 (SCD+2\% O. europaea leaves) were $2117.42,2230.10$, and $2336.66 \mathrm{~g}$, respectively. The results indicated a better growth performance for the Group 3 chicks, which was $>200$ g compared to Group 1 and over $100 \mathrm{~g}$ compared to Group 2 chicks. According to Zahid et al. [33], the powder of $A$. her$b a$-alba used with the SCD in Group 2 improves the health of poultry due to its antibacterial, antioxidant, and antifungal properties. Furthermore, Gholamrezaie et al. [34] demonstrated that the addition of Artemisia leaves in poultry feed has the potential to improve daily weight gain and FCR. In the present study, the daily weight gain was positively affected, but no significant influence had been observed in an FCR. In terms of growth performance, the results with Artemisia in the present study were better than those reported by Cayan and Erener [25], which was measured at the end of rearing chicks weighing about $1840 \mathrm{~g}$. The differences could be explained by different climatic conditions in which the feeding experiments were carried out (hot and humid seasons).

The FCRs of the control group and the two other groups received 2\% feed supplements of Artemisia or olive leaf were generally low although numerically reached $1.79,1.87$, and 1.81 , respectively. The closer the FCR between three groups proves the efficiency of Artemisia or olive leaf powder in diet of chicks as a supplement. The FCR for the feed complemented with the olive leaf powder found in the present work was lower than that reported byCayan and Erener [25], which was $=2.05$. However, it was consistent with those reported by Chaabna [35]. According to Zahid et al. [33], A. herba-alba significantly improves FCR, which could reinforce the theory of high feed efficiency for Artemisia or olive leaf powder.

\section{Serum biochemical parameters}

The results of the selected serum biochemical parameters studied were closer between the different groups, and no statistical differences were observed $(\mathrm{p}>0.05)$, except for cholesterol and glucose, which were significantly lower in the Group 3 chicks, which fed on the diet supplemented with $2 \%$ of the olive leaf powder. Parsaei et al. [36] reported that incorporation of olive leaf into the chick diet significantly decreased the blood values of cholesterol and glucose. Laaboudi et al. [37] demonstrated the hypoglycemic effect of olive leaves to treat diabetic rats, an effect close to that of certain molecules used in diabetes treatments. This effect can be explained by the contents of phenolic compounds in olive leaves extracts, as previously demonstrated by Fki et al. [38]. Despite the many positive effects of supplementing Artemisia into animal feed, cited in the literature, the present work could not show any positive effects on serum biochemical parameters of chicks, compared to the control group.

\section{Conclusion}

The present study demonstrated that the supplementation of Artemisia or olive leaf powder into the broiler diet improved body weight by about $5 \%$ or $10 \%$, respectively, at slaughter with moderate changes in blood biochemical parameters. The present work can contribute to a strategy of reducing the use of conventional poultry feed ingredients, mainly corn and soybeans, which might reduce the importation and production costs of broilers in Algeria.

\section{Authors' Contributions}

AA, MTD, and NM have conceived and designed the study. AA and NM conducted the study in the laboratory. NM and FG analyzed the data and performed statistical analysis. AA, NM, and FG drafted and revised the manuscript. All authors read and approved the final manuscript.

\section{Acknowledgments}

The authors thank "Institut Vétérinaire Tropical de l'Université de Liège", Belgium for covering the publication fee of this article. This research did not receive any specific grant from funding agencies in the public, commercial, or not-for-profit sectors.

\section{Competing Interests}

The authors declare that they have no competing interests.

\section{References}

1. Belhattab, R., Amor, L., Barroso, J.G., Pedro, L.G. and Figueiredo, A.C. (2014) Essential oil from Artemisia herba-alba Asso grown wild in Algeria: Variability assessment and comparison with an updated literature survey. Arab. $J$. Chem., 7(2): 243-251.

2. Mahmoodly, F.F. (2013) Traditional medicines in Africa: An appraisal of ten potent African medicinal plants. Evid. Based Complement. Alternat. Med., Article ID: 617459: 14.

3. Yun, C., Jung, Y., Chun, W., Yang, B., Ryu, J., Lim, C., Kim, J.H., Kim, H. and Cho, S.I. (2016) Anti-inflammatory effects of Artemisia leaf extract in mice with contact dermatitis in vitro and in vivo. Mediat. Inflam., Article ID: 8027537: 8 .

4. Lee, J., Narayan, V.P., Hong, E.Y., Whang, W.K. and Park, T. (2017) Artemisia iwayomogi extract attenuates high-fat diet-induced hypertriglyceridemia in mice: Potential involvement of the adiponectin-AMPK pathway and very low-density lipoprotein assembly in the liver. Int. J. Mol. Sci., 18(8): 1762.

5. Ghazanfar, K., Ganai, B.A., Akbar, S., Mubashir, K., Ahmad, D.S., Younis D.M. and Tantry, M.A. (2014) 
Antidiabetic activity of Artemisia amygdalina decne in streptozotocin-induced diabetic rats. Biomed. Res. Int., 2014 Article ID: 185676: 10.

6. Ene, A.C., Atawodi, S.E. and Fatihu, M.Y. (2014) Acute toxicity of chloroform extract of Artemisia macivera Linn in Swiss albino mice. Br. J. Pharm. Res. 4(15): 1900-1908.

7. Boudjelal, A., Siracusa, L., Henchiri, C., Sarri, M., Vabderrahi, B., Baali, F. and Ruberto, G. (2015) Antidiabetic effects of aqueous infusions of Artemisia herba-alba and Ajuga iva in alloxan-induced diabetic rats. Planta Med., 81(9): 696-704.

8. Hamza, N., Berke, B., Cheze, C., Le Garrec, R., Lassalle, R., Agli, A., Robinson, P., Gin, H. and Moore, N. (2011) Treatment of high fat diet-induced Type 2 diabetes in C57BL/6J mice by two medicinal plants used in traditional treatment of diabetes in the east of Algeria. $J$. Ethnopharmacol., 133(2): 931-933.

9. Mohaddeseh, A.T., Mohammad, R.Y., Elham, M., Mohammad, A.E., Niki, N.M. and Ali, N. (2016) Antileishmanial activity of Artemisia sieberi essential oil against Leishmania infantum in vitro. Adv. Herb. Med., 2(2): 40-46.

10. Rhaffari, L.E., Zaid A. (2008) Pratique de la phytothérapie dans le sud-est du Maroc (Tafilalet): Un savoir empirique pour une pharmacopée rénovée. In: Fleurentin J. (ed.), Pelt J.M. (ed.), Mazars G. (ed.), Lejosne J.C. (trad.), Cabalion Pierre (collab.). Des sources du savoir aux médicaments du futur: actes du $4 \mathrm{e}$ congrès européen d'ethnopharmacologie $=$ From the sources of knowledge to the medicines of the future $=$ proceedings of the $4^{\text {th }}$ European Congress on Ethnopharmocology. Paris (FRA); Metz: IRD; SFE, 2002, p. 293-318. ISBN 2-7099-1504-9.

11. Rafiq, R., Hayek, S.A.,Anyanwu, U., Hardy, B.I., Giddings, V.L., Ibrahim, S.A., Tahergorabi, R. and Kang, H.W. (2016) Antibacterial and antioxidant activities of essential oils from Artemisia herba-alba Asso., Pelargonium capitatum $\times$ radens and Laurus nobilis L. Foods, 5(2): 28.

12. Samuelsson, G. (1951) The blood pressure lowering factor in leaves of Olea europaea. Farm. Revy, 15(1): 229-239.

13. Zarzuelo, A., Duarte, J., Jimenez, J. and Gonzales, M. (1991) Utrilla vasodilator effect of olive leaf. Planta Med., 57(5): 417-419.

14. Hansen, K., Adsersen, A., Christensen, B.S., Brooegger, S., Rosendal, J.S., Nyman, U. and Wagner, S.U. (1996) Isolation of an angiotensin-converting enzyme (ACE) inhibitor from Olea europaea and Olea lancea. Phytomedicine 2(4): 319-332.

15. Al-Azzawie, H. and Al-Hamdani, M.S.S. (2006) Hypoglycemic and antioxidant effect of oleuropein in alloxan-diabetic rabbits. Life Sci., 78(12): 1371-1377.

16. Sato, H., Genet, C., Strehle, A., Thomas, C., Lobstein, A., Wagner, A., Mioskowski, C., Auwerx, J. and Saladin R. (2007) Anti-hyperglycemic activity of a TGR5 agonist isolated from Olea europaea. Biochem. Biophys. Res. Commun. 362(4): 793-798.

17. Sudjana, A.N., D'Orazio, C., Ryan, V., Rasool, N., Ng, J., Islam, N., Riley, T.V. and Hammer, K.A. (2009) Antimicrobial activity of commercial Olea europaea (olive) leaf extract. Int. J. Antimicrob. Agents, 33(5): 461-463.

18. SAS. (2001) Statistical System Institute, User's Guide: Statistics. SAS Institute, Inc., Cary, NC.

19. Houmani, M., Houmani, Z. and Skoula, M. (2004) Intérêt de Artemisia herba-alba Asso. dans l'alimentation du bétail des steppes algériennes. Acta. Bot. Gall., 151(2): 165-172.

20. Kalaisakis, P. (1975) The Science of Feeding Stuffs. School of Agriculture, Athens.

21. Zoiopoulos, P.E. (1983) Study on the Use of Olive by-products in Animal Feeding in Greece. Animal Production and Health Division, FAO, Rome.

22. Muñoz, F., Anguita, T., Lara, L., Suarez, A. and Boza, J.
(1983) The utilisation of olive leaves in goats feeding. $A d v$. Nutr. Anim. Breed., 24(4): 355-358.

23. Alibes, X. and Berge, P. (1983) Valorización de los Subproductos del Olivar Como Alimentos Para los Rumiantes en España. Division de la Production Animale. FAO, Rome.

24. Nigh, H. (1981) Dryland Dairying with the Olive: Five Years and Beyond. Mimeo. R.R. n 1, Port Colborne, Ontario, Canada. p7.

25. Cayan, H. and Erener, G. (2015) Effect of olive leaf (Olea europaea) powder on laying hens performance, egg quality and egg yolk cholesterol levels. Asian Australas. J. Anim. Sci. 28(4): 538-543.

26. Fall-Touré, S., Traoré, E., N'Diaye, K., N'diaye, N.S. and Sèye, B.M. (1997) Use of Faidherbia albida fruits for feeding peasant fattening cattle in groundnut basin in Senegal. Livestock Res. Rural Dev. 9(5): 1-17.

27. Fenardji, F., Klur, M., Fourlon, C. and Fernando, R. (1974) White Artemisia. Rev. Elev. Med. Vet. Pays. Trop. 27(2): 203-206.

28. Aidoud, A. (1989) Les fer armoise blanche (Artemisia herba-alba Asso). II: phytomasse et productivité primaire. Biocénoses, 4(1-2): 70-90.

29. Jae, K.K., Eui-Cheol, S., Ho-Jeong, L., Soo, J.C., Cho, R.K., Soo, H.S., Chang-Ju, K., Gwi, G.P., CheungSeog, P., Hye, K.K., Jong, H.C. and Sang-Wook, S. (2015) Characterization of nutritional composition, antioxidative capacity, and sensory attributes of Seomae mugwort, a native Korean variety of Artemisia argyi H. Lév. and Vaniot. J. Anal. Methods Chem., (4): 1-9.

30. Simonnet, X., Quennoz, M. and Carlen, C. (2008) New Artemisia annua Hybrids with High Artemisinin Content. Vol. 769. XXVII International Horticultural CongressIHC2006: International Symposium on Asian Plants with Unique Horticultural. p371-373.

31. Onimus, M., Vouillot, J.M. and Clerc, G. (2013) Artemisia annua: A Whole Against Malaria. A Program of Local Production for Treatment of Malaria in Poorest Countries. Agricultural Engineer ISARA Lyon, France. p1-28.

32. Onimus, M., Carteron, S. and Lutgen, P. (2013) The surprising efficiency of Artemisia annua powder capsules. Med. Aromat. Plants, (2): 125.

33. Zahid, A.S.S., Khan, M.S. and Sher, H.K. (2014) Comparative anthelmintic efficacy of Caesalpinia crista, Nigella sativa and oxfendazole in broilers with experimentally induced Ascaridia galli infection. Univ. J. Clin. Med., 2(3): 53-57.

34. Gholamrezaie, S.L., Mohammadi, M., Jalali, S.J., Abolghasemi, S.A. and Roostaie, A.M.M. (2013) Extract and leaf powder effect of Artemisia annua on performance, cellular and humoral immunity in broilers. Iran. J. Vet. Res., 14(1): 15-20.

35. Chaabna, N. (2014) Activité Anticoccidienne des Extraits d'Artemisia herba-alba. Magister en Biologie et Physiologie Végétale, Option: Valorisation des Ressources Végétales. Université de Setif, Oujda, Morocco. p91.

36. Parsaei, S., Amini, Z. and Houshmand, M. (2014) Effects of olive leaf on blood metabolites and humoral immunity response of broiler chicks. Int. J. Adv. Biol. Biomed. Res., 2(3): 741-751.

37. Laaboudi, W., Ghanam, J., Ghoumari, O., Sounni, F., Merzouki, M. and Benlemlih, M. (2016) Hypoglycemic and hypolipidemic effects of phenolic olive tree extract in streptozotocin diabetic rats. Int. J. Pharm. Sci., 8(12): 287-291.

38. Fki, I., Sahnoun,Z. and Sayadi, S. (2007)Hypocholesterolemic effects of phenolic extracts and purified hydroxytyrosol recovered from olive mill wastewater in rats fed a cholesterol-rich diet. J. Agric. Food Chem., 55(3): 624-631. 